\title{
Operationalising the Concept of Mediation in L2 Teacher Education
}

\author{
Ghasemali Azadi \\ Department of English Language, Isfahan (Khorasgan) Branch, Islamic Azad University, Isfahan, Iran \\ Reza Biria \\ Department of English Language, Isfahan (Khorasgan) Branch, Islamic Azad University, Isfahan, Iran \\ Mehdi Nasri \\ Department of English Language, Isfahan (Khorasgan) Branch, Islamic Azad University, Isfahan, Iran
}

\begin{abstract}
This study aims to operationlise the mediation concept on L2 teacher education. Sixty-two EFL teachers at Isfahan high schools were selected, a 30-item questionnaire was employed, and T-test and one-way ANOVA were used. The findings revealed mediation roles of the teacher educators were instructional while integrative and participative roles were not attended. Teacher educators presented knowledge, skills, and experiences in the forms of lectures and seminars with little attention to workshops and panel discussions. BA holders showed positive perception towards mediation role of teacher educators while MA holders did not. The least experienced $\mathrm{L} 2$ teachers indicated the most positive attitude towards the mediation role of the teacher educators while the most experienced L2 teachers showed the least positive attitude. The findings presented L2 teachers a deep insight of the mediation concept, teacher educators a better picture of possible flaws of their role, and policy makers to amend related drawbacks.
\end{abstract}

Index Terms-mediation role, mediation tools, teacher educators, L2 teachers

\section{INTRODUCTION}

L2 teacher education incorporating pre-service training courses and in-service development programmes plays a significant role in teacher preparation and classroom presentation. To materialise the role, education policy-makers, teacher educators, and school administrators attempt to outline pedagogy-oriented conventions to turn L2 teachers into more competent professionals. Since it is teacher education that determines to what extent an individual L2 teacher survives in teaching profession as well as functioning effectively in the teaching practice, such education is offered, observed, and assessed in line with the quality consequences. To do so, L2 teachers should not function in isolation, but need to mingle with colleagues, peers and others in a career-directed network. They also need to collaborate and mingle with stakeholders inside and outside school including the members of parent-teacher associations, the members of local councils, researchers, academics, and particularly teacher educators. Such cooperation bears immense benefits for teachers' personal and professional development.

Studies such as Murphy, Scantlebury, \& Milne (2015); Peacock (2009); Turuk (2008); Daniels (2008); Yu (2004); Daniels (2001); Nyikos and Hashimoto (1997); Vygotsky (1986); and Vygotsky (1978) sustain all types of teachinglearning loops to involve a kind of cooperation tied with mediation. The notion of mediation in cognitive development and in teaching and learning interaction initially signifies the role of language as a mediator. As such, language plays a mediational role to assist the learners to reach more competent level. However, the mediation concept has been developed and reinforced by psychologists, theorists, academics, and researchers in self-directed and hyphenated branches of science.

Language as a third party in teaching and learning is a representational device acting as a mediator as it drives human speakers to mediate between their minds and the outside world when they acquire and learn a language (Guerrero, 2007). According to Vygotsky (1962), "direct teaching of concepts is impossible and fruitless. A teacher who tries to do this usually accomplishes nothing but empty verbalism, a parrot-like repetition of words by the child, simulating a knowledge of the corresponding concepts but actually covering up a vacuum" (p. 83). In other words, it is the language that plays a mediational role between what we think and what we learn as inner speech.

Language learner and what he should learn is mediated by the instructor familiarising the learner with new concepts and assisting the learner to involve in the learned material to accommodate it. Vygotsky's notion in education paves the way for teachers and teacher educators to function more interactive, profound, and tangible as a mediator between the knowledge and skills as learnable materials and the students as the learning individuals (Lentof, 2000).

Peers as mediators interact, mediate, and help each other to explore knowledge and practice skills in L1. However, L2 learning can be more facilitated and internalised through "peering" (Guerrero (2007) that is signified as a considerable agent in mediating function in language learning. Villamil and Guerrero (1996) conducted a longitudinal 
study to examine the extent to which peers in the circle of language learners worked together in both writing and speaking processes. The result indicates that the role of peers in assisting language learners is more meaningful than teachers in learners' success if the mingling time is prolonged.

Technology as a mediator is projected in the literature review as it indicates the state of art to the group of studies relevant to the mediation role of technology in learning particularly those that have considered and applied computer as a "mediation tool" (Guerrero, 2007) between those who acquire or learn a language and second or foreign language. The theoretical notion and practical role of technology such as computer and other high-tech gadgets in language teaching and learning started from the middle of the 2oth century "when they were used to replicate the behaviourist approach to teaching" (ibid). As the methods of teaching and learning, particularly in language domain, started to follow the track of change, learning through interaction among learners and other relevant figures such as peers and parents increased. Through using the multimedia software, learners' interest in study is developed, their communication capacity is promoted, teaching effect is improved, interaction between learner and instructor is enhanced, a context for language teaching is created, and flexibility to course content is provided (Shyamlee and Phil, 2012). Currently, hightech means of interaction such as Internet, email exchange, chats, distance learning, etc. encourage both groups of learners and teachers to apply Computer-assisted language learning (CALL) and Computer-assisted language teaching (CALT) in language contexts and language-oriented settings almost all around the world.

Teacher educator as a mediator approximate to the role of teacher. A teacher acts as a mediator between professional knowledge and skills that he attains in teacher education programmes and what he practices in the classroom context. This teaching-learning loop continues when teacher educator as a mediator finds his position between what he achieves through formal acquired knowledge, skills and experience and the teachers who participate in programmes to learn such teaching stuff. The mediation seems more prominent concerning teacher educators and teachers among the stakeholders involved in L2 context when they find their position highly significant pursuing the educational policy makers and preceding the language learners. As such, teacher educators and teachers interact more in a highly scrutinising state so that they engage a bilateral role by which they act as go-betweens in acquiring theoretical and practical premises in some modules and offering them to the learners.

The concept of mediation has been developed to a great extent by distinguished scholars such as Engin (2014), Alsaadi and Mahdi (2013), Xiongyong (2012), Turuk (2008), Mason (2000), Lave and Wenger (1991), and Rogoff (1990), who consider mediated learning beyond a unique phenomenon to children or school students but as an integral part of formal and informal adult learning throughout the world. In this view, learning, whether by children, students or adults, is not an isolated act of cognition, but rather a process of interaction via mediation through which learners learn as other participants such as teachers and peers assist them to learn.

From this point, the role of teacher educator as mediator figures and accordingly the role of teacher education colleges, programmes, and courses as mediator tools are deemed considered. Teacher education colleges mediate to transfer planed materials from education policy-makers to teacher educators. Teacher education programmes act as means to offer the predetermined modules to participant teachers. Teacher education courses specify the teachers' immediate needs and categorise the assigned materials to put in practical presentations meeting teachers' needs. Given such apparent recurring loop in teaching and learning a language, the mediation principle seems more prominent concerning L2 teaching and learning context. In particular, the long process of teaching and learning does not take place in EFL context without mutual interaction via mediational means. As Warschauer (2012) states, those who have been considered highly distinguished figures in any community are those who have learnt their aptitude, knowledge and skills apprenticed into certain social practices through mediation. It signifies that the prosperous language learners, no matter whether they are teachers or learners, should be involved in the loop of teaching, mediating, and learning where they realise the concept of mediation and its subtle qualities.

Mediation concept in teacher education fields- teacher training and teacher development- offers profound insight into the teaching and learning responsibilities, broadens the horizon of involved figures, and assists teachers to deal with quality initiation, continuation and termination of any task in the classroom. According to Vethamani and Kabilan (2008), the survival of teaching profession in both second and foreign language contexts are highly dependent on realisation of such concept of mediation through which learning new theories, knowledge and skills, teaching learners at various levels, testing learners over a range of taught and potential textbook materials, evaluating learners' academic achievements would be facilitated and resulted in satisfactory conclusions both in learning and teaching theories, knowledge and skills on teachers side and learning and applying language on learners side. Figure1 presents the concept of mediation for teacher education in L2 context as interactional trend with subjects-oriented components, administration agents, and recipients of offered services. The multilateral interaction between and among the facets are strongly recommended for an optimal process of learning and teaching carried out by teachers and consequently learning and pertaining by learners. 


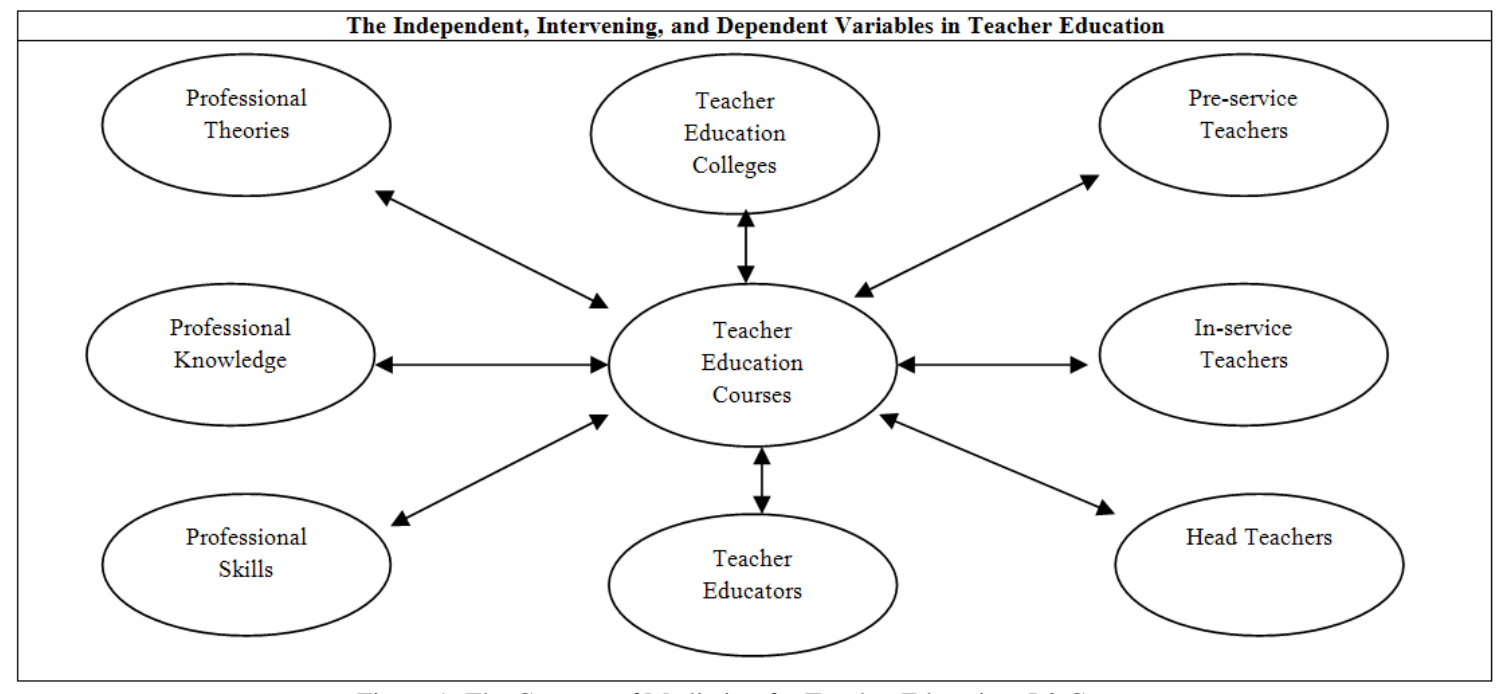

Figure 1: The Concept of Mediation for Teacher Education: L2 Context

Through various kinds of mediations, learning in almost all fields is facilitated, conceptualized and internalized. However, the studies conducted to teacher education have indicated the lack of interaction and mediation between and among L2 teacher educators and L2 teachers. It has led to insufficient internalisation and the application of offered materials in classroom contexts (Fang, 2008, Mirhassani \& Beh-afarin, 2004).

As Rogoff (1990) and Van Huizen, Van Oers, and Wubbles (2005) assert, Vygotskian view indicates the main goal of the teacher education programmes is to enhance and qualify a professional identity that is developed through guided social participation. When teachers are mere listeners and observers, the teaching and learning in teacher education programmes seem pointless and fail to direct the process of acquisition and hinder further development of professional knowledge and skills.

In teacher education programmes, the priority for prospective teacher is to be a professional teacher and for present teacher is to be a more competent teacher as the ideal forms for which the programmes should be combined with an explicit attention to teachers' personal ideas and motives needed to for a quality teacher. Such combination addresses a process of development among prospective and present teachers. However, since the presentation of educators within teacher education programmes is not mutual and teachers are not mingled enough with the teacher educators, teachers' knowledge and knowledge presented in the classroom are critically evaluated. The results indicate that the knowledge and skills presented in the classroom are not conceptualised, not personalised and not appropriated on the side of teachers (Azadi, 2014, Anarisarab \& Mobasheri, 2009). However, in teacher education programmes, teachers' requirements to follow-up personal choices are not met due to pre-organised and pre-planned workshops. L2 teachers conceptualise, personalise, and appropriate the presented materials through the various forms of interaction with educators and enhance their knowledge and skills through the educators' mediation.

\section{LITERATURE REVIEW}

The focus of relevant literature has been mainly placed on the cognitive properties of mediation both in teaching profession and learning progression considering child and L1 acquisition. However, there has taken a twist towards the role of mediation in L2 teacher education. The researchers have taken the zone of proximal development (ZPD) progression into consideration as the proving ground for the multiple interactions for quality teaching and learning. They come up with the idea that teachers should move from the "zone of actual development (ZAD)" (Shabani, 2012); which does not sufficiently involve in the development. It just reflects what is already developed or achieved since it engages the learner in what has been by now acquired and does not consider what should subsequently be learnt. In contrast, it is ZPD in which the level of assisted performance and the potentiality for permanent development are highlighted. Having involved in movement from ZAD to ZPD, teachers go through "cognitive change, experience internalization, and mental development via artefacts and collaboration peers or mentors resting on the concept of mediation" (ibid).

\section{A. Theoretical Perspective}

Socio-cultural school of thought proffered by Vygotsky $(1962 ; 1978)$ has potentially impacted on psychology and education in general and on the conceptualization of language acquisition and teacher-learner interaction in particular. Various perspectives such as Bakhtinian, Language Socialization, and Critical Theory consider mediation a part in learning process; however, it is Vygotskyan perspective that has paid special attention to the role of mediation and regarded it as the core part of perspective. Mediation along with the premise of social learning constitutes the major concepts of socio-cultural theory to shed light on all human activity that is mediated by person, tools or signs (Wertsch 
1991). For Vygotsky, the integration of mediational means not only facilitates learning, but also stabilizes the entire flow and structure of mental functions (Vygotsky 1981). Hence, development in learning principally takes place through a form of mediated apprenticeship with the interaction of student and teachers or student and peers which leads students to advance level through his ZPD.

In short, Vygostkey's socio-cultural views on language teaching and learning provide the explanation of the sociocultural conditions that include achievement processes and mediation processes. Through achievement processes, pedagogy can enhance both teaching and learning that lead to language development and through mediation processes teacher educators and teachers imply new acquired knowledge, skills, and strategies by means of interaction to support learners to reach the further stages (Yu, 2004). In other words, learning and experiencing in collaboration with teacher educators and more capable teachers make L2 teachers take the instructions and use them to organize their independent performance and to handle their own classroom in an efficient approach.

There are factors interwoven to push a teaching profession towards sound application of theories and techniques in the classroom. Figure 2 indicates a mediation model for teacher education in L2 context with contributory factors and the factorial interaction.

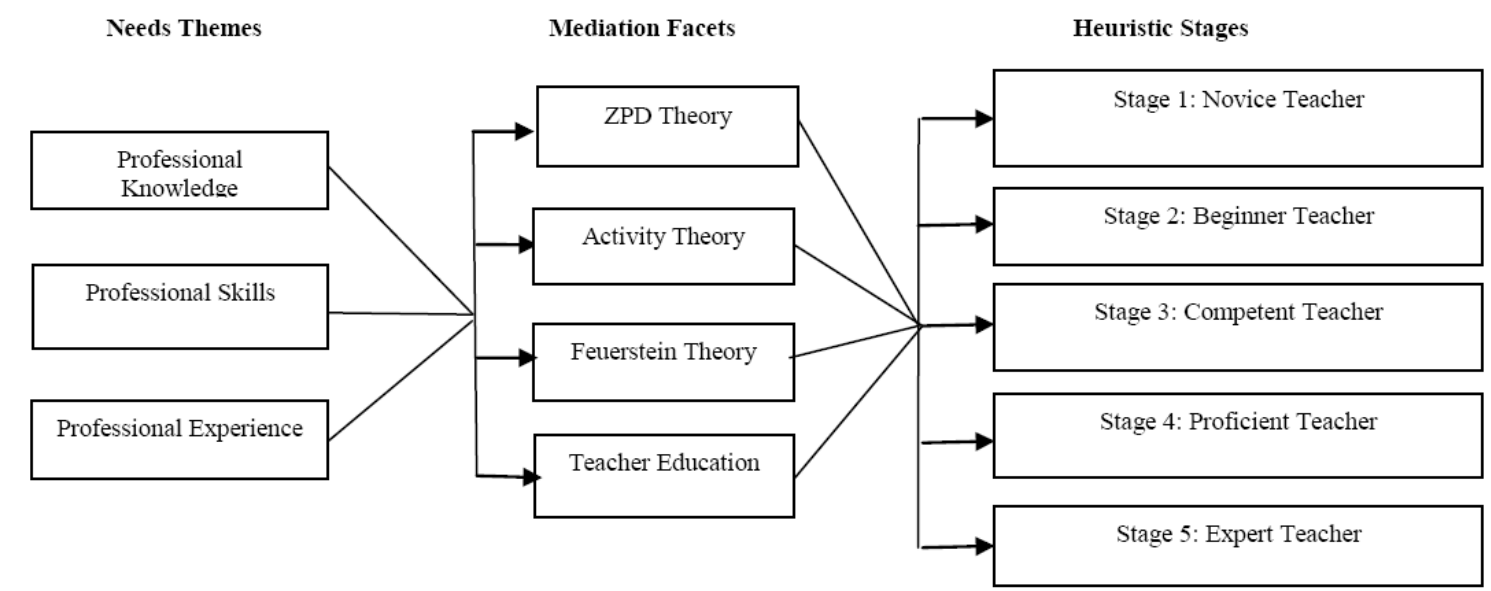

Figure 2: A Mediation Model for Teacher Education: L2 Context

The fundamental needs to meet in L2 teaching and learning for which educational policy makers, teacher educators, school administrators, and teachers should collaborate are of L2 teachers' professional knowledge, professional skills and professional experience required for classroom code of conduct (Azadi, 2014). It is worth mentioning that L2 teachers' professional knowledge as a principle that is theory-specific, L2 teachers' professional skills as a package that is practice-bound and L2 teachers' professional experience as a share ground that is a body of collaborative know-how should be targeted in teacher preparation and teacher development programmes as the focal assertions to pursue in the same scale and with the same weight.

In order to meet the needs of L2 teachers, both pre-service and in-service, concerned figures should consider certain features to enable them to offer the required bits and pieces in the programmes with efficient outcomes. These facets are some theories and premises to employ to fulfil the terms of the programmes. In L2 context, ZPD as a learning space between the current state of teaching knowledge including conceptual and professional knowledge and skills and prospective stage of knowledge to be acquired through the interactive relationship with others (Blanton et al., 2005).

Activity theory developed by Lantolf (2000) suggests that learning as an activity motivated by a need which might be either social or biological. Therefore, learner should go through certain activities which are goal directed and are accomplished under certain social conditions. In the theory, an active role has been outlined for the learners through which he should attempt to know activities and to stay active pursuant to his objectives and accordingly lead the activities towards proper purposes. Through Feuerstein's Theory of Structural Cognitive Modifiability (SCM), a child or even an adult has great chance of positive change and development through mediation. It is even suggested to move beyond mediation of specific external behaviours but to keep internal durable and meaningful changes in cognition which impact the learners' competence (Seng, 2003). The five-stage heuristic model of teacher training and development by Dreyfus and Dreyfus (1986) focuses on the intuition and tacit knowledge or 'knowing how' and argues against the conscious operation or 'knowing that' in learning teaching profession. A teacher relies on his/her personal perception and proficiency rather than a set of rules about how to operate new activities. The model consists of five stages from novice to expert teacher to explain the skills of acquisition.

\section{B. Studies on Mediation}

Previous studies focus on socio-cultural theory and the concept of mediation in education from different perspectives. Xiongyong (2012) raises concerns about EFL teachers' knowledge of mediation at secondary school. The study targets at teachers' cognition of mediation and hypothesises that mediation is ignored by most EFL teachers at secondary school which makes teachers stay away from the mediation role in language setting. However, this study tends to pay 
the way for teachers, teacher educators, educational policy designers, and curriculum developers to apply teaching theories and teaching practices in more meaningful and more profound conduct regarding mediation in teaching and learning English language.

Vygotskian perspective leading to socio-cultural theory that focuses on the interaction in learning between teachers and students or more competent others was well employed by Engin (2014). The study defines scaffolding at the level of interaction as micro-scaffolding, and mentions its support in learning as macro-scaffolding. Targeting pre-service English teacher training context, this study explores macro-scaffolding. Findings of the study indicate that both micro and macro level aspects of teaching are affected. At micro level, practical scaffolding acts and deeds that should be implemented in case-by-case outline; and at macro level, better understanding among the teachers of theoretical features in teacher education that are research based are taken into close consideration (Engin, 2014).

Co-teaching for the school-placement element of pre-service teacher education is the focal scope of the study. The study by Murphy, Scantlebury, and Milne (2015) demonstrates positive impacts of co-teaching on "lessening classroom anxiety, supporting inquiry-based science teaching, improving students' attitudes, and addressing diversity effectively in classrooms". Pre-service and in-service teachers minimise the obvious gap between theory and practice through coteaching as reflective practice and pedagogical content knowledge are enhanced (ibid).

The theory of Feuerstein is taken into consideration by Seng (2003) and the attention is paid to the importance of human mediation as the key to the psychological development of learners in social interactions as well as pedagogy. Mediation is emphasized as it brings about the adaptability of the learner in a form of holistic approach. Through the use of theory, teachers act as (i) facilitators of the learning of heuristics, (ii) mediators of knowledge sources (iii) mediators of lifelong learning and (iv) designers of the learning environment.

Alsaadi and Mahdi (2003) find out the effect of the mediator on scaffolding fourth year student-teachers' teaching competencies and their self-efficacy. The study uses a mediator on scaffolding students affecting teaching competencies and self-efficacy from which the existence of student-teachers' self-awareness is ensured.

Scaffolding used in the classroom to improve student level in primary schools is a focus of some studies. However, although scaffolding plays a key role in teacher education, pre-service teachers may involve in the actual position and application of scaffolding techniques particularly when it has something to do with bilateral and practical applications in the classroom setting. In this regard, Verenikina and Chinnappan (2012) examine the scaffolding notion and application among pre-service teachers. Based on the outcome of their study, scaffolding is highly considered as a proper substitute for traditional and conventional forms of language teaching. Accordingly, it can be concluded that scaffolding positively affects teaching and learning at elementary and intermediate levels. Nevertheless, when it has to involve in theoretical and complex aspects of teaching, there still exist studies indicating uncertainty and dissatisfaction among teachers and researchers.

Socio-cultural Theory is used as an appropriate theory for the ESL classroom because it consists of cultural approach in addition to an educational approach. According to Lee (2015), "the theory has been beneficial for adult learners because it involves social interaction, cultural involvement, and all components of the teaching environment". The paper discusses learner's experience and reflection of teaching English as a second language (ESL) to adult learners through applying mediation on the side of teachers.

A study conducted by Mason (2000) considers the role of teachers with respect to mediating to knowledge. It indicates two roles for a teacher; on the one hand teacher acts restricted part of a facilitator and on the other hand teacher acts as a "critical mediators of knowledge" (ibid). According to the study, the position of teachers mediating the knowledge is rooted in the long philosophical discussions about knowledge and truth. Teacher position as a sociocultural critic, "analogous to the role of art critics, is developed from debates around knowledge, values, and the politics of curriculum design. These two roles are synthesised into teachers as critical mediators of knowledge" (ibid).

Given socio-cultural theory to support learning including L2 acquisition, Turuk (2008) considers the theory as a "semiotic process" placing emphasis on the requirement of attendance in the socially mediated activities. Teaching is tapped required to acquire and develop both foreign and second language considering ZPD to assist the learners to achieve the satisfactory level of attainment in language learning. The study observes learning in both foreign and second language contexts that can better be learnt, attained, and internalised through the collaborative and mediated attempts in a close supportive milieu in which learner should try to learn language beyond isolated individual's effort.

Shabani, Khatib and Ebadi (2010) examine the instructional implications of Vygotsky's seminal notion of ZPD and the role of it in enhancing teaching profession. The study is conducted to test the role and function of some aspects of language teaching based on socio-cultural theory such as "diary writing, peer and mentor collaboration, action research, practicum and TESOL discourse" (ibid). The study also tends to define ZPD role, to offer scaffolding concept, and to pay close attention to the related issues resulted from ZPD and scaffolding premises. It further indicates that ZPD within the framework of dynamic assessment (DA) presents a better perspective regarding the levels of achievement and retention of language in L2 context. This study highlights the limitations of the metaphor of scaffolding in interpreting the ZPD.

Considering the findings of conducted studies and putting the concepts of mediation and social practices together lead us to a wide range of interpretation related to the significance of particular mediators in the practice of learning for various materials and professions with a focus on how learners and teachers cooperate to construct knowledge and skills 
(Wertsch and Bivens 1992). In this perspective, the significance of teacher trainers and teacher educators is not that they provide information and analyze theories in teacher education agenda for both pre and in-service teachers; they should truly act not only as mediators to offer teaching materials in theory, but also as mediators to assist teachers to conceptualize and utilize the novel and developed materials within the classroom in practice. Teacher trainers and teacher educators or independent variables act as "mediating devices" to promote teachers knowledge and skills as dependent variables. Accordingly, this study addresses the following three related research questions:

RQ1. What mediation role do L2 teacher educators act in the development of L2 teachers' profession?

RQ2. How do L2 teacher educators mediate between teacher education programmes and L2 teachers?

RQ3. Is L2 teacher educators' mediation appropriate for classroom application?

\section{METHOD}

The research method of this study is a survey to gather data to describe the nature of existing conditions of the teacher education programmes, existing role of L2 teacher educators, and determining the relationship between L2 teacher educators and L2 teachers within the programmes. Research strategy for data collection and data analysis associated with the research questions is a quantitative research with descriptive survey design. As a survey research, data gathered from respondents who were EFL teachers, using questionnaire composed of closed items in Likert scale with options of Strongly disagree (1), Disagree (2), Undecided (3), Agree (4), and Strongly agree (5).

\section{A. Sampling}

This study was conducted in city of Isfahan. Totally, 62 EFL teachers were randomly chosen from boys' and girls' high schools in five education districts. This study addressed EFL teachers - male and female- in the city of Isfahan who either serve in state or non-profit high schools. They hold either BA or MA degrees in ELT and have taken part in the teacher education programmes.

\section{B. Procedure}

First, the content validity of the questionnaire was judged by the TEFL experts and based on their recommendations; some items in the questionnaire were slightly modified. Then, a pilot study was conducted with 14 EFL teachers who were selected randomly in high schools across the city of Isfahan. Pursuant to their views on the ambiguities of the items, the negative terms were omitted from the face of the questionnaire. To follow the reliability of the research data, obtained data were fed into Social Package for Social Sciences (SPSS) to get the alpha level. The overall internal reliability index for all items in the questionnaire is 0.88 that is considered acceptable in social science (Ary et al. 2002).

\section{Data Analysis}

Descriptive statistics were employed to summarize and describe the sample data. They showed the content number of the items, the number of teachers participating in the study, the mean difference for the presented views, and the standard deviation of the data. Then, T-test was employed to find the significant difference between the means of the EFL teachers' view towards the role of teacher educators as mediators. Furthermore, frequency distribution and percentage proportion of EFL teachers in three experience groups towards the mediation premise were taken into consideration. To do so, one-way ANOVA was employed and the collected data were fed into SPSS to be analyzed pertaining to each variable in the study.

\section{RESULTS}

T-Test was manipulated in order to investigate and compare differences between two group means. The group means for the participants referred to academic qualification meant B.A and M.A. The one-way ANOVA was manipulated to investigate and compare within-subject factors design. The within-subject factors were teaching experience of EFL teachers ranging in three groups: Low (1-10), Moderate (11-20), and High (Above 20).

Figure 4.1 represents that $67 \%$ of the $\mathrm{L} 2$ teachers perceive the mediation role of the teacher educators as instructional, $22 \%$ as participative and $11 \%$ as integrative resource. It can be stated that TEs attend the teacher education programmes principally to provide the L2 teacher with knowledge and skills to be applied in the classroom. 


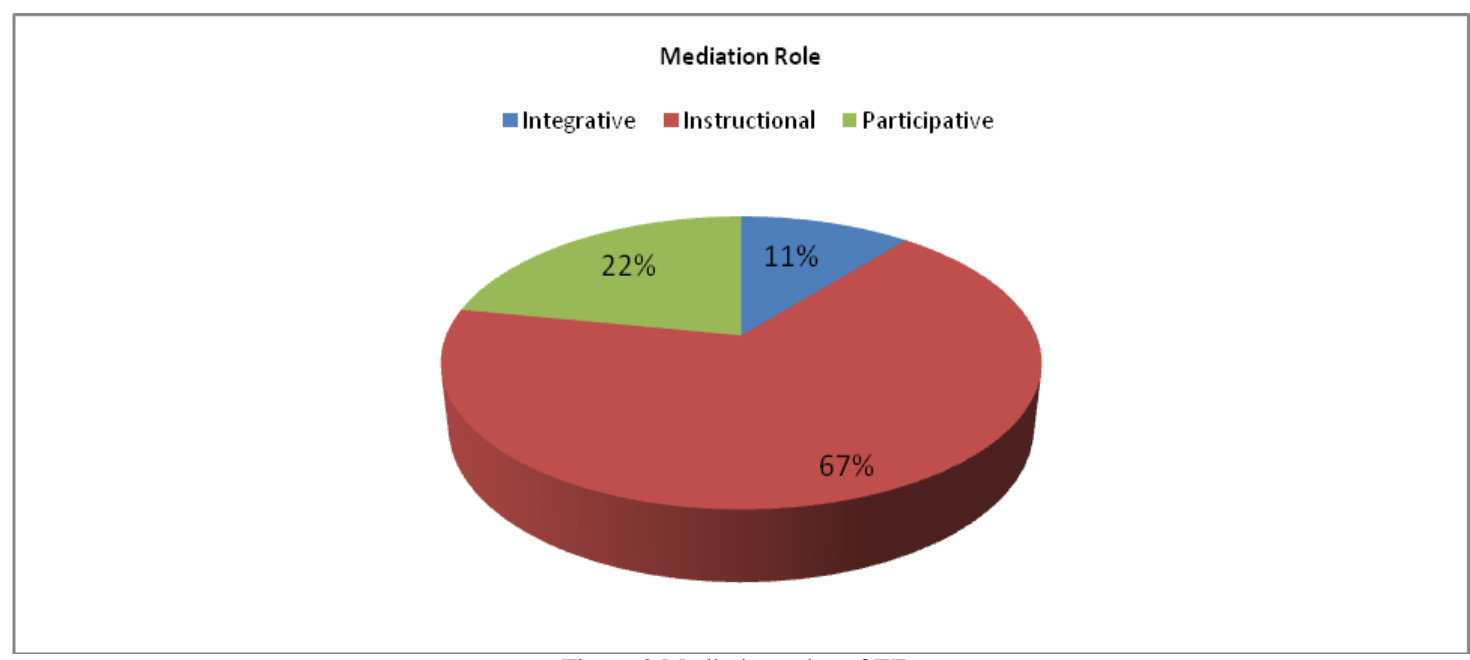

Figure 3 Mediation roles of TEs

Table 4.1 represents that $83 \%$ of the participants indicates that the mediation tools of teacher educators are lectures or seminars while $17 \%$ of the participants shows that the tools are collaborative workshops or panel discussions.

TABLE 1

MEDIATION TOOL OF TES

\begin{tabular}{|l|l|l|l|l|l|}
\hline CATEGORIES & & FREQUENCY & PERCENT & VALID PERCENT & CUMULATIVE PERCENT \\
\hline \multirow{2}{*}{ VALID } & LECTURE/SEMINAR & 51 & 83.0 & 83.0 & 100.0 \\
\cline { 2 - 6 } & WORKSHOP/DISCUSSION & 11 & 17.0 & 17.0 & 17.0 \\
\hline TOTAL & 62 & 100.0 & 100.0 & & \\
\hline
\end{tabular}

Table 4.2 provides means difference between two qualification groups of BA and MA and among three experience groups of teachers: Low, Moderate, and High. The scores were derived from the questionnaire sheets using Likert scale: Strongly disagree (1), Disagree (2), Undecided (3), Agree (4), and Strongly agree (5) to elicit L2 teachers' perception towards the mediation role of the TEs. Some information about the variables, categories in groups, number of the participants, mean, and standard deviation is tabulated respectively.

TABLE 2

MEAN DIFFERENCE OF THE GROUPS

\begin{tabular}{|l|l|l|l|l|}
\hline VARIABLES & CATEGORY & $\mathrm{N}$ & MEAN & STD. DEVIATION \\
\hline \multirow{3}{*}{ QUALIFICATION } & BA & 49 & 3.98 & .409 \\
\cline { 2 - 5 } & MA & 13 & 2.83 & .405 \\
\hline \multirow{5}{*}{ EXPERIENCE } & LOW (1-10) & 12 & 4.02 & .300 \\
\cline { 2 - 5 } & MODERATE (11-20) & 17 & 3.56 & .310 \\
\cline { 2 - 5 } & HIGH (ABOVE 20) & 33 & 3.01 & .405 \\
\hline
\end{tabular}

According to the results of table 4.2, a significant difference was observed in relation to each pair of low, moderate, and high experienced EFL teachers in reference to their perceptions towards the mediation role of teacher educators. It shows that the BA holders bear the mean 3.98 which is considerably higher than MA holders' mean that is 2.83 . Regarding the experience of teachers and their perception of the mediation role of teacher educators, the results show that the highest mean is related to the first group with the least experience, the moderate one is related to the second group, and the lowest mean is related to the third group with the most experience.

\section{DISCUSSION}

L2 teachers are highly recommended to regularly attend the developmental programmes and take advantage from teacher educators' knowledge, skills and experiences in a collaborative interaction (Vethamani and Kabilan, 2008). Realising the role of qualified and attuned teacher educators as mediators, L2 teachers enhance and reinforce teaching theories, classroom practice, matter-of-fact experience, and self-efficacy through interaction with the mediators. According to Nielsen et al. (2007), "attending the classes conducted by exemplary teachers and coaches and observe their teaching methods, strategies and techniques" causes to weigh up, amend, and develop teacher profession. This way of teacher learning makes language teachers cope with their theory-and-practice teaching problems.

In this study, EFL teachers were asked to give their opinions about the mediation role L2 teacher educators have in the development of L2 teachers' profession, the way L2 teacher educators mediate between teacher education programmes and L2 teachers, and if L2 teacher educators' mediation is appropriate for classroom application.

Based on the results of the study relevant to the first research question of the study, most respondents pointed out that the mediation role of the TEs is basically instructional. That is, TEs attend the programmes to teach materials to L2 
teachers with no consideration of bilateral or collaborative interaction. It could be explained by the nature of the participation of the TEs which seems to be helpful source for presenting novel and productive materials especially to the least experienced and the youngest teachers. The study statistically revealed that the participants' expectations of the applications of the knowledge and skills in the real classroom context were met. Findings showed that integrative and participative roles were not considerably attended since majority participants statistically demonstrated that TEs failed to integrate with the teachers to discuss and tackle their teaching issues in more meaningful state. The participants also showed TEs failed to participate in direct group discussions expected by the teachers.

Considering the second research question, TEs offer the knowledge, skills, and experiences for the most part in the forms of lectures and seminars. These mediation tools may pave the way for EFL teachers to apply changes, particularly to teachers' knowledge and skills, so that the teachers can apply the changes productively in the classroom. Teacher showed that little attention is paid to collaborative sessions for reciprocal discussions over teachers' pedagogical issues. The study confirmed the teacher education programmes were held in the form of lectures and seminars in which the educators gave just speeches and teachers just listened to them and there was lack of effective workshops or panel discussions for direct participation of the participant teachers.

The third research question asked whether L2 teacher educators' mediation is appropriate for classroom application. The calculated mean for teachers holding BA shows that they are more in agreement with the role of TEs as mediators than the mean for MA holders. Additionally, teachers with the least experience in English language teaching indicated the most positive attitude towards the mediation role of the TEs while the teachers with the most experience showed the least positive attitude towards the mediation role of TEs.

The principles and theories forming the concept of mediation in L2 teaching/learning loop tend to facilitate the way pedagogical activities are presented, instructed, and evaluated. Mediation is supposed to provide the backbone of teacher education and subsequently classroom instruction. It can be inferred that the success of teacher preparation, classroom presentation and student education must strictly be rooted in the teacher education programmes and the role of teacher educators influencing the participants and the context in which the given materials should be implemented.

\section{REFERENCES}

[1] Alsaadi, S. \& Mahdi, S. (2013). The effect of a mediator on scaffolding EFL student-teachers' teaching competencies, selfefficacy and self-awareness. Journal of College of Education For Women. Vol. 24 (4). 1272-1296.

[2] Ananisarab, M., \& Mobasheri, A. (2009). The impact of short-term pre-service teacher training courses on the teachers' attitude and practice. Roshd FLT Journal, 92 (24), 54-65.

[3] Ary, D., Jacobs, C., \& Razavieh, A. (2002). Introduction to research in education. (6 $6^{\text {th }}$ Ed). USA: Wadsworth Thomson Learning.

[4] Azadi, G. (2014). EFL teachers' perception of professional knowledge through in-service programmes. The Iranian EFL Journal. Vol. 10, (2), 458-474.

[5] Blanton, M. L., Westbrook, S. and Carter G. (2005). Using Valsiner's Zone Theory to Interpret Teaching Practices in Mathematics and Science Classrooms. Journal of Mathematics Teacher Education, 8, 5-33.

[6] Daniels, H. (2008). Pedagogy. In H. Daniels, M. Cole, \& J. V. Wertsch (Eds.), The Cambridge companion to Vygotsky (pp. 307-331). Cambridge: Cambridge University Press.

[7] Daniels, H. (2001). Vygotsky and pedagogy. NY: Routledge/Falmer.

[8] Dreyfus H. L. \& Dreyfus S. E. (1986). Mind over machine. New York: Free Press.

[9] Engin, M. (2014). Questioning to scaffold: an exploration of questions in pre-service teacher training feedback sessions. European Journal of Teacher Education, Vol. 36 (1), 39-54.

[10] Fagan, s (2008). Teachers as Learners: Incorporating Sociocultural Theory into L2 Teacher Education. TESOL \& Applied Linguistics, 2008, Vol. 8, (1), 1-5.

[11] Guerrero, M. C. M. (1996). Krashen's $i+1$ and Vygotsky's ZPD: Really two very different notions. TESOL-GRAM, 9, 9-17.

[12] Guerrero, M. C. M. (2007). Applications of Vygotskyan concept of mediation in SLA. Colombian Applied Linguistics Journal, Vol, 9, 213-228.

[13] Lantolf, J, P. \& S.L. Thorne. (2006). Sociocultural theory and the genesis of second language development. Oxford: Oxford University Press.

[14] Lantolf, J.P., 2000. Introducing sociocultural theory. In: Lantolf, J. P., ed. Sociocultural theory and second language learning. Oxford University Press, 1-26.

[15] Lave, J. (1988). Cognition in practice. New York: Cambridge University Press.

[16] Lave, J., \& Wenger, E. (1991). Situated Learning: Legitimate peripheral participation. Cambridge, MA: Cambridge University Press.

[17] Lee, M. S. (2015). Implementing sociocultural theory while teaching ESL. SPACE, Vol. 1, (1). 28-35.

[18] Mason, M. (2000). Teachers as critical mediators of knowledge. Journal of Philosophy of Education. Vol. 34, (2), 343-352.

[19] Mirhassani, A., \& Beh-afarin, R. (2004). Assessment of needs, pedagogical constraints and objective setting in EFL teacher education programmes (TEPs): EFL Teacher Education Evaluation. Roshd FLT Journal. Vol. 69 (16): 45-57.

[20] Murphy, C,. Scantlebury, K,. \& Milne (2015). Using Vygotsky's zone of proximal development to propose and test an explanatory model for conceptualizing co-teaching in pre-service science teacher education. Asia-Pacific Journal of Teacher Education. Vol. 43, (4), 1-14.

[21] Nielsen D. C., Barry, A. L. \& Staab, P. T. (2007). Teachers' reflections of professional change during a literacy-reform initiative. Teaching and Teacher Education, 24, 1288-1303. 
[22] Nyikos, M., \& Hashimoto, R. (1997). Constructivist theory applied to collaborative learning in teacher education: In search of ZPD. The Modern Language Journal, Vol. 81, (4), 506-517.

[23] Peacock, M. (2009). The evaluation of foreign-language-teacher education programmes. Language Teaching Research, Vol. 13(3), 259-78.

[24] Rogoff, B. (1990). Apprenticeship in thinking, cognitive development in social context. USA: Oxford University Press.

[25] Seng, A. S. H., Pou, L. K. H., \& Tan, O. S. (2003). Mediated learning experience with children. Singapore: McGraw-Hill.

[26] Shabani, k,. Khatib, M. Ebadi, s. (2010). Vygotsky's Zone of Proximal Development: Instructional Implications and Teachers' Professional Development. English Language Teaching Vol. 3, (4), 237-249.

[27] Shabani, K. (2012). Teacher's Professional Development from Vygotskian Optique. Advances in language and literary studies. Vol 3, (2), 101-120.

[28] Shyamlee, S. d, and Phil, M. (2012). Use of Technology in English Language Teaching and Learning": An Analysis. IPEDR, Vol. 33, 150-157.

[29] Turuk, N. (2008). The relevance and implications of vygotsky's sociocultural theory in the second language classroom. Arecls Vol.5, 244-262.

[30] Van Huizen, P., Van Oers, B., \& Wubbels, T. (2005). A Vygotskian perspective on teacher education. Journal of Curriculum Studies, Vol. 37, (3), 269-290.

[31] Verenikina, I. (2012). From theory to practice: What does the metaphor of scaffolding mean to educators today? Outlines, Vol. $6,(2), 5-15$.

[32] Vethamani, M. E., \& Kabilan, M. K. (2008). Practices and issues in English language teacher development. Malaysia: Sabasdi Sdn. Bhd.

[33] Villamil, O. and Guerrero, M. (1996). Peer revision in the L2 classroom: Social-cognitive activities, mediating strategies, and aspects of social behavior. Journal of Second Language Writing. Vol, 5, (1), 51-75.

[34] Vygotsky, L. (1962). Thought and language (E. Hanf-mann \& G. Vakar, Trans.). Cambridge, MA: MIT Press.

[35] Vygotsky, L, S. (1986). Thought and Language. Cambridge, MA: MIT Press.

[36] Vygotsky, L. S. (1978). Mind in Society: the Development of Higher Psychological Processes. Cambridge, MA: Harvard University Press.

[37] Vygotsky, L. S. (1981). The genesis of higher mental functions. In J. V. Wertsch (Ed.), The concept of activity in Soviet psychology (pp. 144 -188). Armonk, NY: M. E. Sharpe.

[38] Wertsch, J. V. (2012). Vygotsky's two minds on the nature of meaning. In C. D. Lee \& P. Smagorinsky (Eds.), Vygotskian perspectives on literacy research: Constructing meaning through collaborative inquiry. 19-30. New York: Cambridge University Press.

[39] Wertsch, J. V. (1991). Voices of the mind: A sociocultural approach to mediated action. Cambridge, MA: Harvard University Press.

[40] Xiongyong, C. (2012). Cognition of mediation among secondary school EFL teachers in China. International Journal of Business and Social Science Vol. 3, (14), 233-245.

[41] Yu, G. (2004). Perception, practice and progress: Significance of scaffolding and zone of proximal development for second or foreign language teachers. Asian EFL Journal, Vol, 6, (4). Retrieved July 2010 from http://www.asian-efljournal.com/december_04_YZ.php.

Ghasemali Azadi is a PhD candidate in TEFL at Islamic Azad University, Isfahan branch-Iran and teaching there as well. His areas of interest include teacher training, testing, L2 methodology, and curriculum development. He has published articles in academic journals such as JALS, ILI, and TPLS. He also has given lectures in national and international conferences such as TELLSLI (9), LPD2012, MICELT2012, and ELT in the Islamic World.

Reza Biria is an Associate Professor of applied linguistics in the Department of Foreign Languages, Islamic Azad University, Isfahan (Khorasgan) Branch, Isfahan, Iran. His research interests include English for academic purposes, EFL writing instruction and second language assessment. He has actively published many articles in national and international journals.

Mehdi Nasri is an MA graduate in TEFL from Islamic Azad University, Isfahan branch-Iran. His field of interest is critical discourse and L2 teacher training. He has been teaching English language in Pooyesh Institute in Isfahan for years. 